\title{
Security and development: Shifting the focus to interpersonal violence
}

\section{Anke Hoeffler}

Anke Hoeffler is a Research Officer at the Center for the Study of African Economies, Department of Economics, University of Oxford. She may be reached at anke.hoeffler@economics.ox.ac.uk.

\section{Abstract}

The focus in the security and development debate is on collective violence and the World Bank's World Development Report 2017 is typical by mainly considering the effects of organized armed conflict. In this article I argue that interpersonal violence affects many more people globally and should receive more attention as well as aid. The adverse consequences from interpersonal violence on socioeconomic development are likely to be large but much of this violence is hidden in plain sight. Women and children are at particularly high risk of being victims of violence but since most of this violence is perpetrated in the domestic sphere it is less likely to affect the collective conscience.

I n nine chapters the World Bank's World Development Report 2017 (WDR 2017, for short) sets out the links among governance, law, and development. One of the chapters is devoted to governance and security. While the World Bank has published a previous flagship report - the World Development Report 2011 on conflict, security, and development (WDR 2011) and has supported research on security - international development agencies still are only paying limited attention to the issue of security. This is, for example, evidenced by devoting very little aid to security-related issues. It is therefore commendable that security issues receive considerable attention in the WDR 2017. Chapter 4 starts with the important premise that security, governance, and power are tightly interlinked and that security is a precondition for development. The definition of security is broad and includes different forms of violence, ranging from civil war to homicides, gang warfare, mafia violence, riots, and on to various traditional practices that harm women. Yet, most of the focus is on civil wars and to a lesser extent on homicides. ${ }^{1}$

While civil war is now understood to be an important impediment to development, there is still little awareness of how other forms of violence harm societal development. This is despite a number of advocacy groups highlighting this issue (e.g., the Geneva Declaration and the Small Arms Survey). Interpersonal violence kills many more people every year than are killed in collective violence. Data from the World Health Organization (WHO) illustrate this point: In 2015 about 624,000 people were killed violently and about 75 percent of these were due to interpersonal violence and not the result of direct violence in collective violence, such as civil war. Moreover, the costs of interpersonal violence are much larger than those resulting from collective violence. A recent estimate suggests that only about two percent of the global costs of violence are due to wars. ${ }^{2}$

The aim of this article is to put the spotlight on some forms of interpersonal violence, sketch out some associated governance and law issues, and indicate how this knowledge can be used to reduce violence. While empirical evidence is used to support the arguments, it is important to stress that the data quality often is poor. Data on violence are available from international agencies such as the World Health Organization (WHO), the United Nations Office on Drugs and Crime (UNODC), and the World Bank. Most of this information is based on officially reported crime data but many acts of violence are never reported. Official data are therefore likely to underestimate the prevalence of violence, and hence it is useful to consult surveys to assess victimization rates, and the discussion of violence against women and children uses this type of information. The data presented in this article should therefore be understood as approximations to provide a sense of magnitude of the problem and to enable a comparison across different countries and regions.

The available evidence suggests that although violence exists in every society, low incomes are associated with a higher prevalence of violence, reinforcing the argument that violence is, at least in part, a development issue. The article is structured as follows. The next section presents some data on homicides, mainly to provide a benchmark for the follow-on sections. Police numbers presented in the discussion on homicide conviction rates suggest that low- and middle-income countries (LIMICs) have relatively small police forces when compared to their armies. The section thereafter provides some of the evidence of violence against women and suggests how this violence can be reduced. Violence against children is the 
Table 1: Prevalence rates of interpersonal violence per 100,000 people (2010)

$\begin{array}{lccc}\text { Region } & \text { Homicide } & \begin{array}{c}\text { Violence } \\ \text { against } \\ \text { women }\end{array} & \begin{array}{c}\text { Violence } \\ \text { against } \\ \text { children }\end{array} \\ \begin{array}{l}\text { Europe \& } \\ \text { Central Asia }\end{array} & 3.0 & 1,665 & 1,336 \\ \begin{array}{l}\text { East Asia \& } \\ \text { Pacific }\end{array} & 3.1 & 2,234 & 4,053 \\ \begin{array}{l}\text { North } \\ \text { America }\end{array} & 3.4 & 653 & 760 \\ \begin{array}{l}\text { South Asia } \\ \text { Middle East } \\ \text { \& North }\end{array} & 4.0 & 4,323 & 11,000 \\ \text { Africa } & 4.2 & 3,011 & 6,919 \\ \begin{array}{l}\text { Sub-Saharan } \\ \text { Africa }\end{array} & 9.6 & 5,807 & 10,072 \\ \begin{array}{l}\text { Latin } \\ \text { America \& } \\ \text { Caribbean }\end{array} & 19.7 & 3,390 & 1,233 \\ & & & \end{array}$

Sources: Homicide: UNODC. Women (intimate partner violence): DHS, and comparable surveys. Children (parental violence): MICS, and comparable surveys. See text for details. I thank James Fearon for help with the data in this table and Figures 1 to 3.

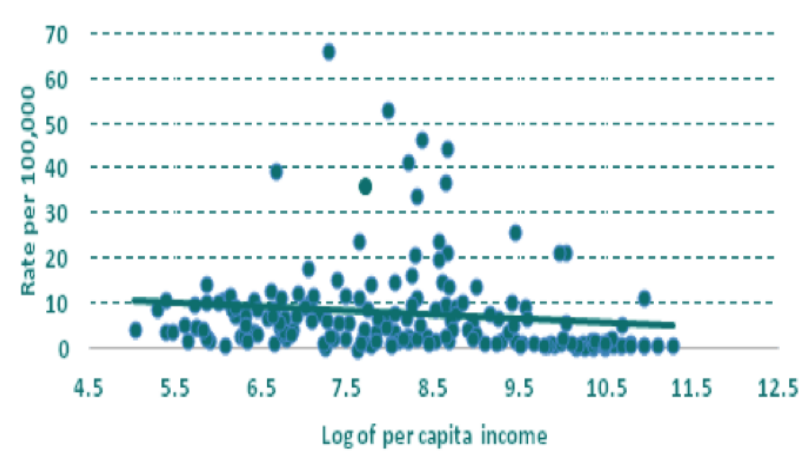

Figure 1: Homicide rates per 100,000 as against log of per capita income (2010). Sources: Income (GDP per capita), World Bank, World Development Indicators. Homicide: UNODC.

focus of the penultimate section, arguing that the development community has so far not understood this type of violence to be a critical issue for development. The last section offers some conclusions.
This article examines data on forms of interpersonal violence such as homicide, violence against women, and violence against children. The evidence suggests that although violence exists everywhere, low-income societies suffer from higher rates of prevalence of violence. This reinforces the argument that violence is, at least in part, a development issue and deserves to be studied just as much as war or other forms of collective violence. Only few countries experience wars, but all countries experience interpersonal violence.

\section{Homicides}

Although there is a clear understanding in the WDR 2017 that high levels of violent crime impose considerable costs on society and constrain economic growth, I want to stress a number of additional issues. The discussion of interpersonal violence starts with homicides, because the data quality is better than for other forms of interpersonal violence and this section provides a useful benchmark. Homicide data are generally seen as the most reliable and internationally comparable violent crime statistics because they are connected to a body. Other violent crimes, such as for example robbery, may not leave behind any physical evidence and many more of these crimes go unreported. Most countries report homicide counts to the UNODC. Indeed, in 2010 almost all countries (195) reported their homicide data. In order to compare these data across countries they are expressed in rates per 100,000 people in the population. For 2010, Figure 1 is a scatter plot of the logarithm of per capita income and the homicide rate. Homicide rates vary considerably across the world. For example, Jamaica had a homicide rate of nearly 60 per 100,000 , Malawi of 36, the United States of about 5, and Norway just under 0.7 . The WHO considers a rate of 10 or greater as epidemic, and 45 countries have such high homicide rates. Only a weak negative correlation between income and homicide exists, due to the large dispersion of homicide rates, in particular across middle income countries. Many of the countries with high homicide rates and middle incomes are in Latin America and the Caribbean. (Also see Table 1, column 1 which displays the average homicide rates by region.) In Latin America and the Caribbean interpersonal violence is ranked as the fifth-leading cause of death, and it is the top killer among boys and young men aged $15-29 .^{3}$

The WDR 2017 provides a very useful overview of how homicide rates can be reduced. Some countries, e.g. Australia, Brazil, and the United States have significantly reduced homicide rates in the recent past. A first order condition is that states establish a monopoly on violence, but changes in norms of behavior are also important. Steven Pinker argues that the "rights revolutions" made aggression and violence less 
Table 2: Police, armed forces, and judges per 100,000 (2010)

$\begin{array}{lccc}\begin{array}{l}\text { Country income level } \\ \text { Low income }\end{array} & \text { Police } & \begin{array}{c}\text { Armed } \\ \text { forces }\end{array} & \text { Judges } \\ \text { Lower middle income } & 204 & 586 & 8 \\ \text { Upper middle income } & 417 & 725 & 13 \\ \text { High income } & 418 & 720 & 17 \\ & & 599 & 3 \\ \begin{array}{l}\text { Sources: Armed Forces: World Bank, World Development } \\ \text { Indicators. Police and judges: UNODC. Note: For income } \\ \text { cutoffs, see endnote 5. }\end{array}\end{array}$

acceptable over the past few decades. By this he broadly understands that the civil rights movement, the feminist movement, and the gay rights movement argued for peaceful change, spread the idea of equality, and lobbied for public policy changes. Two additional factors that decrease the levels of violence are, first, a change in demographics which resulted in the presence of proportionally fewer adolescents and young adults who are both, the main perpetrators and victims of (fatal) violence and, second, the increased use of security technology such as burglar alarms in cars and homes and CCTV cameras. Property crimes and violent crimes are linked and since much of property crime is opportunistic, these technologies act as a deterrence to such crime and therefore also to violent crime. ${ }^{4}$

To establish the monopoly on violence and guarantee personal security, all sizeable countries have a police force and an army. The role of the police is to deter violence and to provide security through the apprehension of criminals. If it is true that "more police and more police presence have been shown causally to lead to declines in crime" (WDR 2017, p. 117), then it is important to consider the quantity and quality of policing that countries should provide. Although the optimal size of a police force is not obvious, there is evidence that LIMICs may be undersupplying security as their police forces are relatively small. To make a comparison across countries, consider the average number of police, armed forces, and judges per 100,000 people. These data are supplied by the World Bank and the UNODC, but are unlikely to be defined in the same way across reporting countries. For example, the inclusion of paramilitary groups in some countries within the police force is clearly problematic. Keeping these issues in mind, Table 2 shows that, on average, low-income countries have a much lower state capacity, i.e., they have far fewer police officers, soldiers, and judges. ${ }^{5}$ On average, low-income countries have 116 police officers per 100,000 people in the population and high-income countries have 418. Similarly for the armed forces, where there are 599 per 100,000 in lowincome countries as compared to 720 in high-income countries. Moreover, low-income countries appear to be mainly concerned with military security as they maintain relatively large armies in comparison to their police forces. Their armies are only 17 percent smaller than those of high-income countries, but their police forces are 72 percent smaller. Thus, in the international comparison, low-income countries do appear to undersupply security through police.

There can only be a police deterrence effect when perpetrators are apprehended, tried, and sanctioned. Conviction rates are, therefore, important in the strategy of reducing homicides and these rates do not only depend on the numbers of police. Homicide conviction rates vary considerably across countries. According to a 2013 UNODC report, perpetrators were only convicted for 24 percent of all homicides committed in the Americas. These rates are higher for Asia (48 percent) and Europe ( 81 percent). There are a number of reasons why the level of impunity is so high in the Americas but the nature of the homicides is likely to be important. Securing convictions is easier when the suspects are intimate partners or family members, but much more difficult when the homicide was committed by members of organized crime. Societies with high levels of organized crime also are often corrupt, leading to a weakening of the state. Corruption payments not only inhibit current criminal investigation and conviction of suspects but they also decrease the capability of the criminal justice system in the longer term. Corruption attracts individuals more interested in receiving private rewards rather than serving the public. This adverse selection reduces the quality of public officials in the criminal justice system. In addition, civil servants in countries with very high levels of organized crime also suffer intimidation, threats, and violence, making them less likely to investigate all homicides. To illustrate the danger of taking public office, consider these figures from Mexico: 147 mayors, 49 former mayors, and 8 mayoral candidates are believed to have been killed by criminal organizations from 2005 through December 2016. One consequence of corruption and adverse selection is low trust in the police force. Survey evidence from Latin America shows that trust in the police is low and that ordinary citizens perceive police corruption as a major problem. On average 16 percent of the respondents said they trusted the police "not at all," and a remarkable 42 percent responded that "the police are involved in crime." Compare this to surveys for the U.S. and Canada, where the percentages saying that they trusted the police "not at all" were 6.9 and 5.2 percent respectively, while the question about police involvement in crime was not even asked. ${ }^{6}$ 


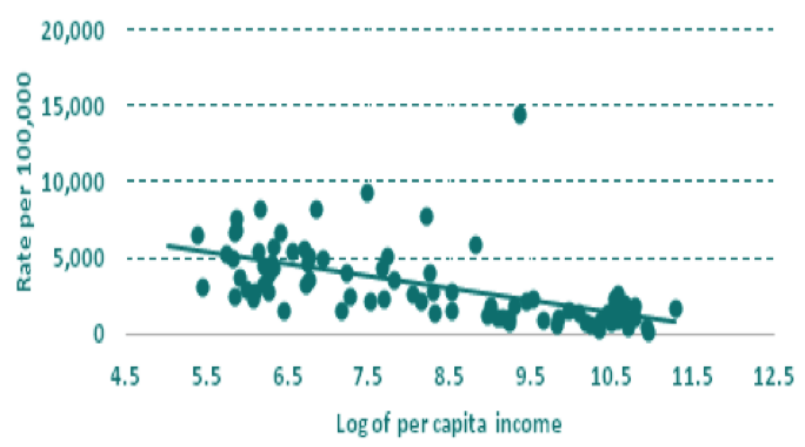

Figure 2: Rates of violence against women per 100,000 as against log of per capita income (2010). Sources: Income (GDP per capita), World Bank, World Development Indicators. Intimate partner violence: DHS and comparable surveys.

In a word, many governments are not providing effective, efficient, and accountable policing to serve and protect the population, and police numbers are comparatively low in LIMICs. To reduce homicides, a data-driven, evidence-based, and problem-oriented approach will help to apply scarce resources effectively. For example, in many cities more than half of all homicides occur in less than two percent of street addresses. Prevention strategies must include strategies to restrict access to weapons, in particular firearms, and the abuse of alcohol. More generally, homicide rates decline when states establish good governance, an effective rule of law, curb the corruption of state officials, gain control over private protection markets, and enhance state legitimacy through inclusive institutions. $^{7}$

\section{Violence against women}

As is true for all violence, the immediate effect of violence against women is pain and suffering, of course, but it has many other, and far-reaching, consequences. Gender-based violence represses women's voices and restricts their agency. It prevents women from fulfilling their potential and, in the aggregate, this violence harms societal and economic development. Women's equality and empowerment are important goals for the World Bank. This is evidenced by a recent report on empowering women and girls. Likewise, the UN and the WHO have published a number of reports specifically on violence against women, highlighting violence as a violation of human rights, as a problem of discrimination, and as a public health issue. ${ }^{8}$

The WDR 2017 also specifically comments on gender-based violence, power, and norms and makes a persuasive case to change the prevailing patriarchal power structures in many cultures. However, it is striking that while the Report highlights harmful cultural practices, e.g., female genital mutilation (FGM), the maltreatment of women who do not bear male children, and sex-selective abortions, it does not comment on the "everyday violence" inflicted on women around the world. The main perpetrators of this violence are women's intimate partners, i.e., their husbands, partners, or boyfriends. This is a serious omission because about 30 percent of all women experience some form of intimate partner violence during their lifetime. The data on nonfatal intimate partner violence mainly are based on the domestic violence module in Demographic and Health Surveys (DHS). Examples of reported physical and sexual intimate partner violence include being slapped, pushed, shoved, punched, kicked, beaten, choked, burnt on purpose, threatened with a weapon, physically forced to have sexual intercourse, having sexual intercourse because of fear what a partner might do, and being forced to do something sexual that is perceived as humiliating or degrading. When it comes to fatal violence, intimate partners are the largest group of perpetrators: About 43 percent of all female homicide victims were killed by a current or former intimate partner. ${ }^{9}$

The link between economic development and intimate partner violence is illustrated in Figure 2 and in Table 1, column 2. As mentioned, the main data are based on the domestic violence module in Demographic and Health Surveys (DHS). In line with the discussion on homicide rates, annual prevalence is expressed as rate per 100,000 and the relationship with income is negative: Women in lower-income countries are at higher risk of intimate partner violence, especially in Sub-Saharan Africa.

How can this low level of personal security for women be improved? Programs aimed at economic empowerment, such as (un)conditional cash transfers and micro-finance programs so far provide mixed results. In some programs the levels of domestic violence rose while others were effective in reducing the number of child marriages and extending the years of schooling for girls. ${ }^{10}$

As the WDR 2017 points out, a notion about " collectively shared norms about women's subordinate role in society" often is employed to justify the use of violence against them so that it becomes an "acceptable" use of force. For example, DHS data for Sub-Saharan Africa shows that 55 percent of all women, and 37 percent of all men, state that husbands are justified in beating their wives in any of these five scenarios: going out without telling him, neglecting the children, arguing with him, refusing to have sexual intercourse with him, or burning the food. Another example is that rape within marriage is not explicitly criminalized in many countries. Thus, what is considered violence against women is a social construct and, correspondingly, national laws vary considerably. In 2015, 
according to a survey by the World Bank, the majority of countries had laws on domestic violence and sexual harassment in employment, but a number of countries have neither laws against domestic violence nor sexual harassment: Afghanistan, Cameroon, Chad, the Republic of Congo, Djibouti, Equatorial Guinea, Gabon, Guinea, Haiti, Iran, Mali, Mauritania, Oman, Russia, South Sudan, Swaziland, and Uzbekistan. ${ }^{11}$

As a rule, legal protection from intimate partner violence is weaker in low-income than in high(er)-income countries and there are fewer law enforcement officers to ensure the application of the existing laws. Moreover, not only are the number of laws and police important: Even if countries have codified laws criminalizing partner violence, the reality may still be very different. Common law and traditional practices may carry more importance in everyday life and laws are simply not applied. For example, female genital mutilation is outlawed in 26 African countries but, according to UNICEF, making this practice illegal has had no impact on the number of girls being mutilated. Thus, when legal norms run counter to social norms, legislative reform only has a limited effect on changing attitudes and practices. The deeper, underlying question therefore is how social norms can be changed. ${ }^{12}$

There is some evidence that "infotainment" can help to raise awareness of intimate partner violence and influence norms for the better. For example, in 2016 a popular soap opera aired on BBC Radio 4. Run over several months, it was a detailed story regarding intimate partner violence and resulted in a 20 percent increase of phone calls to U.K. helplines. The soap opera "Soul City," in South Africa, resulted in a 41 percent increase in the use of a domestic violence hotline and an increase in people disagreeing that domestic violence was a private affair (a 20 percentage points increase). In Uganda the "SASA!" program (Kiswahili, meaning "Now!") included a campaign for the prevention of domestic violence. This halved levels of violence and significantly promoted the view that violence against a partner is unacceptable. ${ }^{13}$

Among the programs that target individuals, so-called "dating violence programs" appear particularly promising. Evidence from the DHS domestic violence modules suggest that intimate partner violence is higher among teenagers than other age groups. For example, in Haiti about 16 percent of women suffered physical or sexual partner violence during year prior to the survey but this prevalence rate was more than double for teenagers (15-19 years old). There is evidence that teaching safe and healthy relationships decreases the incidence of sexual assault, increases knowledge of intimate partner violence, and reduces physical and sexual partner violence among teenagers. Such programs have been evaluated in the U.S. and Canada, with studies suggesting a significant decrease in dating violence following from the programs. Interventions for these age groups are likely to have long-lasting effects because very often men and women experience behavior that they repeat later in life. ${ }^{14}$

\section{Violence against children}

In the WDR 2017, there is little mention of violence against children, suggesting that this is not a type of violence that is considered to be a concern for development. In contrast, this section argues why violence against children should be considered a critical issue for socioeconomic development. The emphasis here is on socioeconomic, because there already exists a large literature documenting that childhood exposure to violence not only causes immediate pain and suffering but carries life-long consequences for individual development. Violence disrupts social and psychological learning processes and adversely affects brain development. Longitudinal and cohort studies for the United States show that childhood violence increases the likelihood of criminal behavior, leads to higher rates of self-harm among women and criminal behavior among men in Denmark, as well as increased substance abuse in the U.S. ${ }^{15}$

The main perpetrators of violence against children are their parents and most of the detrimental effects are attributed to the decrease in parental attachment. Children who are hit by their parents feel less secure in their attachment at a young age and as adolescents. Children who feel less secure are more likely to internalize problems resulting in mental health problems and self-harm or they externalize them through aggression and violence. $^{16}$

While this short discussion of the consequences can only provide a glimpse of this research, the evidence suggests that childhood violence has a considerable impact on children's wellbeing and their future personal development. Elsewhere I argue that childhood violence has considerable consequences for socioeconomic development because, in the aggregate, human capital and earnings potential will be lower, societies will see higher rates of antisocial behavior, more (violent) crime, higher prevalence of intimate partner violence, and future corporal punishment of children. Additionally, considerable health consequences arise due to higher rates of depression, anxiety, and higher rates of risky sexual behavior (STDs, unwanted pregnancies, abortions). Although the evidence largely is based on high-income countries, the emerging literature from LIMICs provides similar results. ${ }^{17}$

It is difficult to define what constitutes violence against children, and there is no globally accepted definition. Article 19 of the United Nations Convention on the Rights of the Child of 1989 obliges the signatories to take appropriate measures to protect children from all forms of physical violence while in the 
care of parents or other caretakers. In contrast, the African Charter on the Rights and Welfare of the Child allows the administration of domestic discipline, but stipulating that "this must be applied with humanity and be consistent with the inherent dignity of the child" (Article 20,1c). Thus, in an African context there seems to be no fundamental contradiction between a child's dignity and physical punishment. It has been argued that UN conventions are based on Western values and do not reflect the beliefs and practices in the Global South. In addition to the diverging views on what constitutes acceptable harm, cultural notions of childhood are diverse. The childhood studies literature argues that the understanding of childhood is shaped by age, gender, ethnicity, history, and location. This is in contrast to the UN convention where children are defined as any person under 18 years and are given universal rights. ${ }^{18}$

Without a global definition of violence against children and without comparable statistics, such as victimization surveys as in the case of intimate partner violence, data are difficult to raise. Many of the child victims would be too young, anyway, to be included in a survey. Many countries, especially those with low incomes, do not keep records on child abuse and neglect because child protection services are unavailable or the legal systems are dysfunctional. But even in countries with good child protection services, child abuse is massively underreported. In many cases, the victims never report the abuse. This may be for a number of reasons, for example because they are too young to report the violence or because they have a limited understanding of what constitutes abuse and neglect, they feel ashamed, and they think nobody will believe them. Many perpetrators are able to use their power to intimidate their victims into keeping silent about the abuse, or alternative care situations are difficult or impossible to arrange, and children thus feel they have to put up with their violent environment. So, even if states collect official statistics they will be unreliable due to low disclosure rates. ${ }^{19}$

In the absence of a global definition and readily available data, I follow literature precedent and employ data on the use of physical punishment by parents as a proxy of violence against children. The expressions "corporal punishment" and "physical punishment" are used interchangeably. The UN's Multiple Indicator Cluster Surveys (MICS) provide data on parental discipline techniques and have been used in a number of reports, and in research. In these MICS surveys, primary care givers (mainly mothers) were asked about child disciplinary practices at home, including: $:^{20}$

- Nonviolent discipline (e.g., gave him/her something else to do, explaining why behavior was wrong, taking away privileges);
- Psychological aggression (e.g., shouted at him/her, called him/her dumb or lazy);

- Physical punishment (e.g., shook him/her, spanked, hit with bare hand on the bottom or other parts of the body, hit with a belt, stick, or other hard object on the bottom/other parts of the body); and/or

- Severe physical punishment (e.g., hit or slapped him/her on the face, head or ears, beat him/her with an implement repeatedly).

Using the responses to construct a proxy of violence against children requires some judgement. While some argue that any corporal punishment constitutes child abuse, this is in contrast to prevailing norms where many parents do not consider slapping or spanking their children as abusive. The medical and public health literatures do not put forward a definition of what constitutes violence against children. Expressions such as "child maltreatment," "abuse," and "adverse childhood experiences" are used but no universally accepted definition of these categories exists. Based on the assumption that the consequences are likely to be greater if the violence is more severe, I restrict the discussion to severe physical punishment, the last category in the four point list above. Psychological aggression, although damaging to children, is also excluded because it is difficult to find a common definition and because it is difficult to compare to physical aggression. Severe physical punishment, such as repeated beating with a belt or cane, is more likely to be recognized across the world as abusive toward children. This is important, because even in societies where some form of corporal punishment is the norm, there are limiting parameters that distinguish acceptable from unacceptable forms of adult physical aggression toward children. There is also a close link between physical punishment and more severe child abuse: Often such abuse started with physically punishing the child. ${ }^{21}$

Using the MICS data, a rate of severe child punishment per 100,000 was calculated. Figure 3 shows care-givers in lowincome countries reporting higher rates of severe punishment when compared to those in high-income countries. The size of any reporting bias is unclear. In societies where child physical punishment is the norm, parents may even overstate the use of harsh discipline methods, while parents in other societies may be reluctant to report the true extent of their use of such punishment. Thus, the gradient of the regression line in Figure 3 may be flatter than indicated there. Table 1, column 3 also suggests that low-income regions have higher rates of severe child punishment.

What do the laws against corporal punishment tell us about the importance governments attach to the problem of violence 


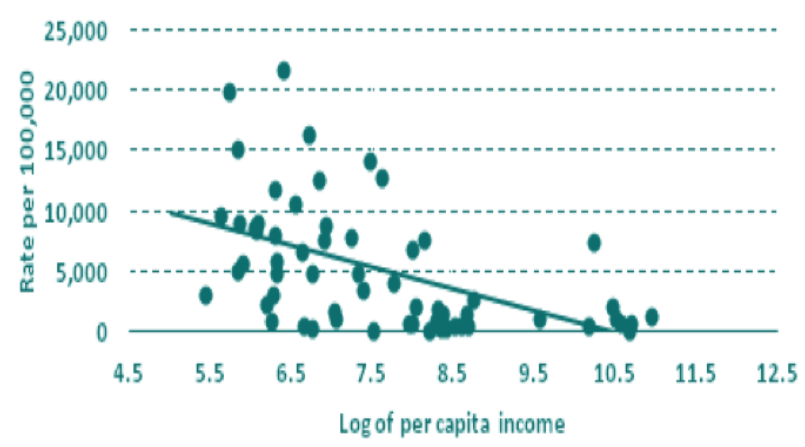

Figure 3: Rates of violence against children per 100,000 as against log of per capita income (2010). Sources: Income (GDP per capita), World Bank, World Development Indicators. Parental violence: MICS and comparable surveys.

against children? Currently just 55 states prohibit corporal punishment in all settings, including the home, and 130 states have outlawed corporal punishment in schools. However, detailed evidence from the Young Lives Project suggests that even in states where teachers are not allowed to use corporal punishment, many school children still report being physically disciplined. $^{22}$

If laws do not necessarily change behavior, what other options are there? One promising intervention are parenting programs. Originating in social learning theory, they focus on teaching parenting skills and knowledge about raising children. The emphasis lies on establishing a strong child-parent bond through praise and nonviolent discipline methods. Referred to as "positive parenting," a number of different programs exist, for example, the Incredible Years Parent Training (IYPT), Positive Parenting Program (Triple P), and Parenting for Lifelong Health (a WHO and UNICEF initiative). Although originally designed in high-income countries, this type of intervention has been carried out many countries. Parenting programs have been subjected to rigorous evaluations and the evidence suggests that they can substantially reduce the maltreatment of children. Although only a small number of parenting programs have been applied in low- and middleincome countries, the evidence is encouraging. Even when programs are transported to countries different from where they originated, parenting programs appear to be at least as effective. This is supported by recent evidence from Liberia, Uganda, and Kenya. There is also some emerging evidence that early childhood development programs (e.g., pre-school programs) have the potential to reduce violence over the long term in Latin America. For these interventions context matters but a recent review suggests that important lessons can be drawn from high- income countries. ${ }^{23}$

\section{Conclusion}

The main concern in the WDR 2017 lies with organized armed conflict. In contrast, the aim of this article is to put a spotlight on interpersonal violence. Only few countries experience (civil) war or other collective violence but all countries experience interpersonal violence. The discussion centers on the prevalence of three types of violence: homicide, intimate partner violence, and violence against children. Violence can only be measured imprecisely but all of the available cross-country evidence suggests that violence is most prevalent in low-income countries. Large dispersions in the data suggest that cultural differences matter. Here, culture is understood as a society's shared beliefs and norms that guide their members' actions. Internalized social norms influence individual attitudes and the ways in which people behave. Norms that support violence can be used to justify violent behavior and practices and can therefore play a key role both in the perpetration of violent behavior at individual and community levels and in shaping the responses of both victims and institutions. Today, violence against women receives much more attention in the development research and policy community than in the past, in part because gender-based violence is understood as discrimination, a human rights violation, a public health issue, and as a development problem. It is less clear how societal gender norms can be changed, but new legislative initiatives and information campaigns suggest that we are witnessing a global transformation. Specific interventions, such as educational programs aimed at teenagers, can significantly reduce intimate partner violence. In contrast, violence against children is not commonly perceived as a development problem. Yet a large body of research provides evidence that this form of violence not only inflicts immediate pain, suffering, and harm on the child but carries severe adverse effects on the physical and mental development of individuals. Victims are less likely to fulfill their inherent potential and, in the aggregate, this may have negative consequences on socioeconomic development. (This is conjecture at the moment and more research is needed to provide evidence to support this claim.) Most violence against children is committed by their parents. Parenting interventions have shown how to effectively reduce harsh parenting practices, suggesting that this type of violence can be reduced. ${ }^{24}$

External aid for "legal and judicial development," including initiatives to improve policing and programs to change violence-related norms, is currently very small; the total amount of overseas aid targeted at the prevention and treatment of interpersonal violence has been put at less than one half of one 
percent. Given the large problems caused by interpersonal violence with regard to human rights violations, public health, and economic development, the international aid community should give more priority to the prevention of interpersonal violence. As the discussion suggested, violence is not something we have to bear without recourse to help. We now have at hand plenty of evidence-based policy suggestions that could be put into practice. ${ }^{25}$

\section{Notes}

I thank Jurgen Brauer and two anonymous referees for helpful comments and suggestions. All remaining errors are my own.

1. Supported research on security: See, e.g., Collier, et al. (2003). Little aid to security-related issues: Fearon and Hoeffler (2014).

2. Advocacy groups: http://www.genevadeclaration.org/ and http://www.smallarmssurvey.org/ [accessed 28 February 2018]. 624,000 people: Data by Mc Evoy and Hideg (2017, p. 21) for the same year (2015) suggest that 76 percent of violent deaths were due to interpersonal violence. Work by the Geneva Declaration Secretariat (2017, p. 51) suggests an even higher percentage of about 86 , but their figures are based on averages for the years 2001-2012. However, it is important to point out that people do not only die due to violence in organized armed conflicts (direct deaths); they also die due to malnutrition and disease (indirect deaths). These indirect deaths are estimated to be considerably higher than the direct deaths (Muggah, 2015). Recent estimate: Hoeffler (2017a).

3. WHO: See the WHO's Global Health Estimates at http://www.who.int/healthinfo/global_burden_disease/estimat es/en/index 1.html [accessed 19 October 2017]. The data quality of the UNODC and WHO data are discussed in Andersson and Kazemian (2017) and in Kanis, et al. (2017).

4. Useful overview: Spotlight 5: Crime (WDR, 2017, pp. 133-135). Rights revolution: Pinker (2011). Change in demographics: Baumer and Wolff (2014) refer to this as improved "youth oversight." Opportunistic: Gash (2016).

5. The World Bank defines low-income economies as those with a gross national income, or GNI, per capita of USD1,005 or less in 2016 and high-income economies are those with a GNI per capita of USD12,236 or more. The full definition of income classification and country lists can be found at https://datahelpdesk.worldbank.org/knowledgebase/articles/9 06519-world-bank-country-and-lending-groups [accessed 8 March 2018].

6. Danger of taking public office: See Heinle, Molzahn, and Shirk (2017). Surveys in the U.S. and Canada: These numbers are based on Latinobarometer. Evidence from the Afrobarometer is similar. See discussion in Fearon and Hoeffler (2014).
7. More than half: Muggah and de Carvalho (2016). Prevention strategies: See, e.g., WHO (2010). More generally: Eisner (2015).

8. Recent report: World Bank (2014). UN and WHO: See, e.g., UN (2015), WHO (2013).

9. Specifically comments: WDR (2017, p. 114). 30 percent of women: Devries, et al. (2013). Perpetrators: Stöckl, et al., (2013)

10. Mixed results: World Bank (2014, chapter 3).

11. WDR quote: WDR 2017, p. 114. DHS data: Cools and Kotsadam (2017). A number of countries: The evidence is based on a World Bank (2015) report, using evidence from 173 countries. Liberia only recently introduced a law on domestic violence through outgoing president's Ellen Johnson Sirleaf executive order in January 2018. The UN (2011) report provides further discussion on the rights of women.

12. Attitudes and practices: UNICEF (2013). See also Platteau and Wahhaj (2014) for a detailed discussion on the interaction between traditional customs and modern statutory law.

13. South Africa and Uganda: Information taken from the World Bank (2014, chapter 3).

14. Haiti, 16 percent of women: Gage, Hoeffler, and Honoré (2017). Decreases: Sinclair, et al. (2013). Increases: Gage, Honoré, and Deleon (2016). Reduces: Foshee, et al. (2004); Lundgren and Amin (2015); Peskin, et al. (2014); Taylor, et al. (2013); Wolfe, et al. (2009).

15. Large literature: See, e.g., Gilbert, et al. (2009), Norman et al. (2012), Sara and Lappin (2017). Disrupts learning: See, e.g., Straus, Douglas, and Medeiros (2014). Brain development: See, e.g., Danese and Baldwin (2017), Nemeroff (2004, 2016). Likelihood of criminal behavior: Straus, Sugarman, and GilesSims (1997). Denmark: Webb, et al. (2017). Increased substance abuse: Scheidell, et al. (2017).

16. Main perpetrators: Pinheiro (2006). At young age: Coyl, Roggman, and Newland (2002). As adolescents: Palmer and Hollin (2001).

17. Elsewhere: Hoeffler (2017b). Emerging literature: See Know Violence in Childhood (2017), Shiva Kumar, et al. (2017), and the other articles in the special issue in vol. 22 of Psychology, Health and Medicine (2017).

18. It has been argued: Renteln (2013). Cultural notions of childhood: See discussion in Jenks (2005), Scheper-Hughes and Sargent (1998). Childhood studies literature: Qvortrup, et al. (2009).

19. Dysfunctional: Marcus (2014).

20. Precedent: Fearon and Hoeffler (2014) and Pereznieto, et al. (2014). Proxy of violence: Know Violence in Childhood (2017) understands violence against children much more broadly. They include, e.g., any form of parental violence as well as violence in school from teachers and peers. Child disciplinary practices: The Parent-Child Conflict Tactics Scale was developed by Straus, et al. (1998). Reports and in research: See, e.g., 
UNICEF (2010, 2014), Akmatov (2011).

21. Some argue: Freeman and Saunders (2014). In contrast to prevailing norms: Straus, Douglas, and Medeiros (2014). Close link: Whipple and Richey (1997).

22. 55 states: See http://www.endcorporalpunishment.org/, [accessed 3 October 2017]. Detailed evidence: See Guerrero and Rojas (2016), Morrow and Singh (2016), Pankhurst, Negussie, and Mulugeta (2016), Vu (2016).

23. Social learning theory: Bandura (1977). Rigorous evaluations: See, e.g., Barlow, et al. (2006), Piquero, et al. (2016), Prinz, et al. (2009). Transported to different countries: Knerr, Gardner, and Cluver (2013). Recent evidence: See the Special Section in the European Journal of Development Research, Vol. 29, No. 5, on Violence Against Children and, in particular, Guisto, et al. (2017), van Esch and de Haan (2017), and Siu, et al. (2017). Recent review: Chioda (2017).

24. Norms that support violence: UNICEF (2013, p. 146).

25. Less than one half of one percent: Fearon and Hoeffler (2014).

\section{References}

Akmatov M. 2011. "Child Abuse in 28 Developing and Transitional Countries: Results from the Multiple Indicator Cluster Surveys." International Journal of Epidemiology. Vol. 40, pp. 219-227.

https://doi.org/10.1093/ije/dyq168

Andersson, C. and K. Lazemian. 2017. "Reliability and Validity of Cross-National Homicide Data: A Comparison of UN and WHO Data." International Journal of Comparative and Applied Criminal Justice. Pp. 1-16. (Published online 11 September 2017.]

Bandura, A. 1977. Social Learning Theory. Oxford, UK: Prentice-Hall.

Barlow, J., I. Johnston, D. Kendrick, L. Polnay, and S. StewartBrown. 2006. "Individual and Group-Based Parenting Programmes for the Treatment of Physical Child Abuse and Neglect." Cochrane Database of Systematic Reviews. Issue 3. Art. No. CD005463. https://doi.org/10.1002/14651858.CD005463.pub2

Baumer, E.P. and K.T. Wolff. 2014. "The Breadth and Causes of Contemporary Cross-National Homicide Trends." Crime and Justice. Vol. 43, pp. 231-287.

https://doi.org/10.1086/677663

Chioda, L. 2017. "Stop the Violence in Latin America: A Look at Prevention from Cradle to Adulthood." Latin American Development Forum. Washington, D.C.: World Bank. https://openknowledge.worldbank.org/handle/10986/ 25920. https://doi.org/10.1596/978-1-4648-0664-3

Collier, P., L. Elliot. H. Hegre, A. Hoeffler, M. Reynal Querol, and N. Sambanis. 2003. Breaking the Conflict Trap: Civil War and Development Policy. Washington, D.C.: World Bank.

Cools, S. and A. Kotsadam. 2017. "Resources and Intimate
Partner Violence in Sub-Saharan Africa." World Development. Vol. 95, pp. 211-230. https://doi.org/10.1016/j.worlddev.2017.02.027

Coyl, D.D., L.A. Roggman, and L.A. Newland. 2002. "Stress, Maternal Depression, and Negative Mother-Infant Interactions in Relation to Infant Attachment." Infant Mental Health Journal. Vol. 23, Nos. 1-2, pp. 145-163. https://doi.org/10.1002/imhj.10009

Danese, A. and J.R. Baldwin. 2017. "Hidden Wounds? Inflammatory Links Between Childhood Trauma and Psychopathology." Annual Review of Psychology. Vol. 68, pp. $517-544$.

https://doi.org/10.1146/annurev-psych-010416-044208

Devries, K.M., J.Y. Mak, C. García-Moreno, M. Petzold, J.C. Child, G. Falder, S. Lim, L.J. Bacchus, R.E. Engell, L. Rosenfeld, and C. Pallitto. 2013. "The Global Prevalence of Intimate Partner Violence Against Women." Science. Vol. 340, No. 6140, pp. 1527-1528. https://doi.org/10.1126/science. 1240937

Eisner, M. 2015. "How to Reduce Homicide by $50 \%$ in the Next 30 Years." Homicide Dispatch 1. Rio de Janeiro: IGARAPÉ Institute.

Fearon, J. and A. Hoeffler. 2014. "Benefits and Costs of the Conflict and Violence Targets for the Post-2015 Development Agenda." Copenhagen: Copenhagen Consensus Center. http://www.copenhagenconsensus.com/ publication/post-2015-consensus-conflict-and-violence-as sessment-hoeffler-fearon.

Foshee, V.A., K.E. Bauman, S.T. Ennett, G.F. Linder, T. Benefield, and C. Suchindran. 2004. "Assessing the Long-Term Effects of the Safe Dates Program and a Booster in Preventing and Reducing Adolescent Dating Violence Victimization and Perpetration." American Journal of Public Health. Vol. 94, No. 4, pp. 619-624. https://doi.org/10.2105/AJPH.94.4.619

Freeman, M. and B.J. Saunders. 2014. "Can we Conquer Child Abuse if we Don't Outlaw Physical Chastisement of Children?" The International Journal of Children's Rights. Vol. 22, No. 4, pp. 681-709. https://doi.org/10.1163/15718182-02204002

Gage, A.J., J.G. Honoré, and J. Deleon. 2016. "Short-Term Effects of a Violence-Prevention Curriculum on Knowledge of Dating Violence Among High School Students in Port-au-Prince, Haiti." Journal of Communication in Healthcare. Vol. 9, No. 3, pp. 178-189. https://doi.org/10.1080/17538068.2016.1205300

Gage, A., A. Hoeffler, and J.G. Honoré. 2017. "Domestic Violence in Haiti." Copenhagen: Copenhagen Consensus Center. Mimeo.

Gash, T. 2016. Criminal: The Truth About Why People do Bad Things. London: Penguin.

Geneva Declaration Secretariat. 2015. Global Burden of Armed Violence 2015: Every Body Counts. Cambridge, UK: Cambridge University Press.

Gilbert, R., C.S. Widom, K. Browne, D. Fergusson, E. Webb, and S. Janson. 2009. "Burden and Consequences of Child 
Maltreatment in High-Income Countries." The Lancet. Vol. 373, No. 9657, pp. 68-81.

https:/doi.org/10.1016/S0140-6736(08)61706-7

Guerrero, G. and V. Rojas. 2016. "Understanding Children's Experiences of Violence in Peru: Evidence from Young Lives.” Innocenti Working Paper 2016-17. UNICEF Office of Research. Florence, Italy: UNICEF.

Guisto, A., E. Friis, A. Sim, R. Chase, J. Zayzay, E. Green, and E. Puffer. 2017. "A Qualitative Study of Mechanisms Underlying Effects of a Parenting Intervention in Rural Liberia." European Journal of Development Research. Vol. 29, No. 5, pp. 964-982. https://doi.org/10.1057/s41287-017-0101-8

Heinle, K., C. Molzahn, and D.A. Shirk. 2017. "Drug Violence in Mexico." Justice in Mexico. Department of Political Science and International Relations. San Diego: University of San Diego.

Hoeffler, A., 2017a. "What are the Costs of Violence?" Politics, Philosophy \& Economics. Vol. 16, No. 4, pp. 422-445.

https://doi.org/10.1177/1470594X17714270

Hoeffler, A. 2017b. "Violence against Children: A Critical Issue for Development." European Journal of Development Research. Vol. 29, No. 5, pp. 945-963. https://doi.org/10.1057/s41287-017-0107-2

Jenks, C. 2005. Childhood. 2nd ed. New York: Routledge.

Kanis, S., S.F. Messner, M.P. Eisner, and W. Heitmeyer. 2017. "A Cautionary Note About the Use of Estimated Homicide Data for Cross-National Research." Homicide Studies. Vol. 21, No. 4, pp. 312-324. https://doi.org/10.1177/1088767917715670

Knerr, W., F. Gardner, and L. Cluver. 2013. "Improving Positive Parenting Skills and Reducing Harsh and Abusive Parenting in Low- and Middle-Income Countries: A Systematic Review." Prevention Science. Vol. 14, No. 4, pp. 352-363. https://doi.org/10.1007/s11121-012-0314-1

Know Violence in Childhood. 2017. Ending Violence in Childhood. Global Report 2017. New Delhi: Know Violence in Childhood.

Lundgren, R. and A. Amin. 2015. "Addressing Intimate Partner Violence and Sexual Violence Among Adolescents: Emerging Evidence of Effectiveness." Journal of Adolescent Health. Vol. 56, No. 1, pp. S42-S50. https://doi.org/10.1016/j.jadohealth.2014.08.012

Marcus, R. 2014. "Child Protection Violations and Poverty in Low- and Middle-Income Countries." Background Note. London: Overseas Development Institute. https://www.odi.org/sites/odi.org.uk/files/odi-assets/publi cations-opinion-files/9303.pdf [accessed 21 August 2017].

Mc Evoy, C. and G. Hideg. 2017. "Global Violent Deaths 2017: Time to Decide." Small Arms Survey. Graduate Institute of International and Development Studies. Geneva: Small Arms Survey.

Morrow, V. and R. Singh. 2016. 'Understanding Children's Experiences of Violence in Andhra Pradesh and Telegana,
India: Evidence from Young Lives.” Innocenti Working Paper 2016-19. UNICEF Office of Research. Florence, Italy: UNICEF.

Muggah, R. 2015. "Counting Conflict Deaths: Options for SDG 16.1." Briefing Note to Members of the Inter-Agency and Expert Group on SDG Indicators." Rio de Janeiro: IGARAPÉ Institute.

Muggah, R. and I.S. de Carvalho. 2016. "The End of Homicide: How to Halve Global Murders in a Decade." Foreign Affairs. 7 September 2016.

Nemeroff, C.B. 2004. "Neurobiological Consequences of Childhood Trauma." The Journal of Clinical Psychiatry. Vol. 65, pp. 18-28.

Nemeroff, C.B. 2016. "Paradise Lost: The Neurobiological and Clinical Consequences of Child Abuse and Neglect." Neuron. Vol. 89, No. 5, pp. 892-909.

https://doi.org/10.1016/j.neuron.2016.01.019

Norman, R.E., M. Byambaa, R. De, A. Butchart, J. Scott, and T. Vos. 2012. "The Long-Term Health Consequences of Child Physical Abuse, Emotional Abuse, and Neglect: A Systematic Review and Meta-Analysis." PLoS Med. Vol. 9, No. 11, p. e1001349.

https://doi.org/10.1371/journal.pmed.1001349

Palmer, E.J. and C.R. Hollin. 2001. "Sociomoral Reasoning, Perceptions of Parenting and Self-Reported Delinquency in Adolescents." Applied Cognitive Psychology. Vol. 15, No. 1, pp. $85-100$.

https://doi.org/10.1002/1099-0720(200101/02)15:1\% 3C85::AID-ACP691\%3E3.0.CO;2-6

Pankhurst, A., N. Negussie, and E. Mulugeta. 2016. "Understanding Children's Experiences of Violence in Ethiopia: Evidence from Young Lives.” Innocenti Working Paper 2016-25. UNICEF Office of Research. Florence, Italy: UNICEF.

Pereznieto, P., A. Montes, S. Routier, and L Langston. 2014. "The Costs and Economic Impact of Violence Against Children. Research Reports and Studies." London: Overseas Development Institute. http://www.odi.org/sites/ odi.org.uk/files/odi-assets/publications-opinion-files/9177 .pdf.

Peskin, M.F., C.M. Markham, R. Shegog, E.R. Baumler, R.C. Addy, and S.R. Tortolero. 2014. "Effects of the It's Your Game ... Keep It Real Program on Dating Violence in Ethnic-Minority Middle School Youths: A Group Randomized Trial." American Journal of Public Health. Vol. 104, No. 8, pp. 1471-1477.

https://doi.org/10.2105/AJPH.2014.301902

Platteau, J.P. and Z. Wahhaj. 2014. "Strategic Interactions Between Modern Law and Custom," pp. 633-678 in V. Ginsburgh and D. Throsby, eds. Handbook of the Economics of Art and Culture. Vol. 2. Amsterdam: Elsevier and North-Holland.

https://doi.org/10.1016/B978-0-444-53776-8.00022-2

Pinheiro, P.S. 2006. World Report on Violence Against Children. New York: United Nations.

Pinker, S. 2011. The Better Angels of our Nature: The Decline 
of Violence in History and its Causes. London: Penguin.

Piquero, A.R., W.G. Jennings, B. Diamond, D.P. Farrington, R.E. Tremblay, B.C. Welsh, and J.M.R. Gonzalez. 2016. “A Meta-Analysis Update on the Effects of Early Family/Parent Training Programs on Antisocial Behavior and Delinquency." Journal of Experimental Criminology. Vol. 12, No. 2, pp. 229-248. https://doi.org/10.1007/s11292-016-9256-0

Prinz, R.J., M.R. Sanders, C.J. Shapiro, D.J. Whitaker, and J.R. Lutzker. 2009. "Population-Based Prevention of Child Maltreatment: The US Triple P System Population Trial." Prevention Science. Vol. 10, No. 1, pp. 1-12. https://doi.org/10.1007/s11121-009-0123-3

Qvortrup, J., W.A. Corsaro, M. Honig, and G. Valentine. 2009. The Palgrave Handbook of Childhood Studies. Basingstoke, UK: Palgrave Macmillan. https://doi.org/10.1057/9780230274686

Renteln, A.D. 2013. International Human Rights: Universalism versus Relativism. New Orleans, LA: Quid Pro Books.

Sara, G. and J. Lappin. 2017. “Childhood Trauma: Psychiatry’s Greatest Public Health Challenge?" The Lancet Public Health. Vol. 2, pp. 300-301. https://doi.org/10.1016/S2468-2667(17)30104-4

Scheidell, J.D., K. Quinn, S.P. McGorray, B.C. Frueh, N.N. Beharie, L.B. Cottler, and M.R. Khan. 2017. "Childhood Traumatic Experiences and the Association with Marijuana and Cocaine Use in Adolescence through Adulthood." Addiction. Forthcoming.

Scheper-Hughes, N. and C.F. Sargent. eds. 1998. Small Wars: The Cultural Politics of Childhood. Berkeley, CA: The University of California Press.

Shiva Kumar, A.K., V. Stern, R. Subrahmanian, L. Sherr, P. Burton, N. Guerra, R. Muggah, M. Samms-Vaughan, C. Watts, and S.K. Mehta. 2017. "Ending Violence in Childhood: A Global Imperative." Psychology, Health and Medicine. Vol. 22, S1, pp. 1-16.

https://doi.org/10.1080/13548506.2017.1287409

Sinclair, J., L. Sinclair, E. Otieno, M. Mulinge, C. Kapphahn, N.H. Golden. 2013. "A Self-Defense Program Reduces the Incidence of Sexual Assault in Kenyan Adolescent Girls." Journal of Adolescent Health. Vol. 53, No. 3, pp. 374-380. https://doi.org/10.1016/j.jadohealth.2013.04.008

Siu, G., D. Wight, C. Namutebi, R. Sekiwunga, F. Zalwango, S. Kasule, and J. Seeley. 2017. "Men's Involvement in a Parenting Programme for Reduction of Gender-Based Violence and Child Maltreatment: Formative Evaluation in Uganda." European Journal of Development Research. Vol. 29, No., 5, pp. 1017-1037.

Stöckl, H., K. Devries, A. Rotstein, N. Abrahams, J. Campbell, C. Watts, and C.G. Moreno. 2013. "The Global Prevalence of Intimate Partner Homicide: A Systematic Review." The Lancet. Vol. 382, No. 9895, pp. 859-865. https://doi.org/10.1016/S0140-6736(13)61030-2

Straus, M.A., E.M. Douglas, and R.A. Medeiros. 2014. The Primordial Violence: Spanking Children, Psychological Development, Violence, and Crime. London: Routledge.
Straus, M.A., S.L. Hamby, D. Finkelhor, D.W. Moore, and D. Runyan. 1998. "Identification of Child Maltreatment with the Parent-Child Conflict Tactics Scales: Development and Psychometric Data for a National Sample of American Parents." Child Abuse \& Neglect. Vol. 22, No. 4, pp. 249-270.

https://doi.org/10.1016/S0145-2134(97)00174-9

Straus, M.A., D.B. Sugarman, and J. Giles-Sims. 1997. "Spanking by Parents and Subsequent Antisocial Behavior of Children." Archives of Pediatrics \& Adolescent Medicine. Vol. 151, No. 8, pp. 761-767.

https://doi.org/10.1001/archpedi.1997.02170450011002

Taylor, B.G., N.D. Stein, E.A. Mumford, and D. Woods. 2013. "Shifting Boundaries: An Experimental Evaluation of a Dating Violence Prevention Program in Middle Schools." Prevention Science. Vol. 14, No. 1, pp. 64-76. https://doi.org/10.1007/s11121-012-0293-2

[UN] United Nations. 2015. The World's Women 2015: Trends and Statistics. Department of Economic and Social Affairs, Statistics Division. New York: United Nations.

[UNICEF] United Nations International Children's Emergency Fund. 2010. Child Disciplinary Practices at Home: Evidence from a Range of Low- and Middle- Income Countries. New York: UNICEF.

[UNICEF] United Nations International Children's Emergency Fund. 2013. Female Genital Mutilation/Cutting: A Statistical Overview and Exploration of the Dynamics of Change. New York: UNICEF.

[UNICEF] United Nations International Children's Emergency Fund. 2014. Hidden in Plain Sight: A Statistical Analysis of Violence Against Children. New York: UNICEF.

[UNODC] United Nations Office on Drugs and Crime. 2013. Global Study on Homidice 2013, Trends Contexts, Data. Vienaa: UNODC.

Van Esch, E. and M. de Haan. 2017. "Evaluating Programs Across Cultural Contexts: A Perspective on the Deficit Narrative." European Journal of Development Research. Vol. 29, No. 5, pp. 983-998. https://doi.org/10.1057/s41287-017-0102-7

$\mathrm{Vu}$, Thi Thanh Huong. 2016. "Understanding Children's Experiences of Violence in Viet Nam: Evidence from Young Lives." Innocenti Working Paper 2016-26. UNICEF Office of Research. Florence, Italy: UNICEF.

Webb, R.T., S. Antonsen, M.J. Carr, L. Appleby, C.B. Pedersen, and P.L. Mok. 2017. "Self-Harm and Violent Criminality Among Young People who Experienced Trauma-Related Hospital Admission During Childhood: A Danish National Cohort Study." The Lancet Public Health. Vol. 2, No. 7, pp. e314-e322. https://doi.org/10.1016/S2468-2667(17)30094-4

Whipple, E.E. and C.A. Richey. 1997. "Crossing the Line from Physical Discipline to Child Abuse: How Much is Too Much?" Child Abuse \& Neglect. Vol. 21, No. 5, pp. 431-444. https://doi.org/10.1016/S0145-2134(97)00004-5

[WHO] World Health Organization. 2010. Violence Prevention: 
The Evidence. Geneva: World Health Organization.

[WHO] World Health Organization. 2013. Global and Regional Estimates of Violence Against Women: Prevalence and Health Effects of Intimate Partner Violence and Non-Partner Violence. Geneva: World Health Organization.

Wolfe, D.A., C. Crooks, P. Jaffe, D. Chiodo, R. Hughes, W. Ellis, L. Stitt, and A. Donner. 2009. "A School-Based Program to Prevent Adolescent Dating Violence: A Cluster Randomized Trial." Archives of Pediatrics \& Adolescent Medicine. Vol. 163, No. 8, pp. 692-699.

https://doi.org/10.1001/archpediatrics.2009.69

World Bank. 2011. World Development Report 2011: Conflict, Security, and Development. Washington, D.C.: The World Bank.

World Bank. 2014. Voice and Agency: Empowering Women and Girls for Shared Prosperity. Washington, D.C.: The World Bank.

World Bank. 2017. World Development Report 2017: Governance and the Law. Washington, D.C.: The World Bank. 